\title{
New Anticandidous 2-Alkylthio-6-aminobenzothiazoles
}

\author{
Eva Sidóová ${ }^{*}$, Dusan $\operatorname{Loos}^{1}$, Helena Bujdákováa and Jana Kallová \\ ${ }^{1}$ Institute of Chemistry and ${ }^{2}$ Department of Microbiology and Virology, Faculty of Natural Sciences, Comenius \\ University, Mlynská dolina, SK-842 15 Bratislava, Slovak Republic. Tel. +42 7 796305; Fax 427728882 \\ (organika@fns.uniba.sk)
}

Received: 19 October 1996 / Accepted: 26 November 1996 / Published: 25 February 1997

\begin{abstract}
The synthesis and antimicrobial activity of six new 2-alkenyl-6-aminobenzothiazoles are reported. The new compounds were prepared by alkenylation of the potassium salt of 6-amino-2-mercaptobenzothiazole with alkenyl bromides. The structure of the compounds was verified by ${ }^{1} \mathrm{H}$ NMR spectra. The compounds have shown antibacterial activity against Staphylococcus aureus and anticandidous activity against Candida albicans. The optimum structure of the studied compounds has been calculated by quantum chemistry AM1 method. The theoretical values of lipophilicity were calculated for all alkenyl substituents.
\end{abstract}

Keywords: 2-Alkenylthio-6-aminobenzothiazoles, anticandidous, antibacterial, AM1 calculations, lipophilicity.

\section{Introduction}

2-Alkylthio-6-aminobenzothiazoles have manifested a large scale of biological activity [1]. Their antimycobacterial activity in vitro is significant both against typical and atypical strains of tuberculous mycobacteria. In comparison with isonicotine hydrazide, a known antituberculous agent, the acute toxicity of the majority of tested 2-alkythio-6-aminobenzothiazoles is $4-8$ times lower [1]. Antimycobacterial tests have shown that the amino group at position 6 functions as pharmacophore. Substitution of the hydrogen atoms in this amino group causes decrease of water solubility, increase of lipophilicity and worse transport in the organism. The result is higher stability of the compounds, but loss of in vivo efficiency as well.

As the title compounds have shown some anticandidous activity [1], later on they were tested for

* To whom correspondence should be addressed. anticandidous, antifungal and anti-yeast activity more thoroughly [2-6]. The tests have manifested very interesting anticandidous activity, as some of the derivatives inhibit yeast - mycelial conversion of Candida albicans, the n-pentyl derivative being the best of them [2, 5, 7, 8]. 6-Acetamido-2-n-pentylthiobenzothiazole inhibits yeast - mycelial conversion of Candida albicans as well, but its low solubility is a bad prognosis for possible medicinal use [9].

The synthesis of new 2-alkylthio-6-aminobenzothiazoles was targeted to get further anticandidous compounds of high activity. As a double bond in the alkyl chain, as well as branching of the chain, can cause a positive or negative change in the anticandidous activity [1], six new alkenyl derivatives $\mathrm{C}_{4}-\mathrm{C}_{6}$ were synthesized in order to combine double bond with the optimal chain length. 


\section{Results and Discussion}

Six new 2-alkenylthio-6-aminobenzothiazoles 1 - 6 have been prepared and identified (Table 1). Their structure has been verified by ${ }^{1} \mathrm{H}$ NMR spectra. The ${ }^{1} \mathrm{H}$ NMR spectra of the new compounds show signals of 6aminobenzothiazole skeleton which are influenced by -SR

Table 1. Characterization of the prepared 2-alkenylthio-6-aminobenzothiazoles.

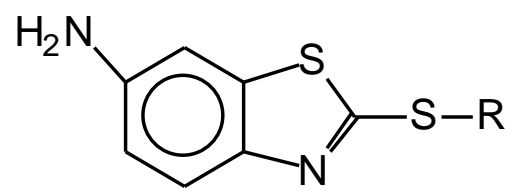

\begin{tabular}{llllll}
\hline & & \multicolumn{3}{c}{$\mathrm{W}_{\mathrm{i}}$ (calc.) $/ \%$} \\
Compound & $\mathrm{R}$ & Formula & $\mathrm{W}_{\mathrm{i}}$ (found.)/\% & Yield/\% & M.p. $\left({ }^{\circ} \mathrm{C}\right)$ \\
& $\mathrm{M}_{\mathrm{r}}$ & $\mathrm{C}$ & $\mathrm{H}$ & $\mathrm{N}$ & $\mathrm{S}$
\end{tabular}

1

$$
-\mathrm{CH}_{2}-\mathrm{CH}_{2}-\mathrm{CH}=\mathrm{CH}_{2} \quad \mathrm{C}_{11} \mathrm{H}_{12} \mathrm{~N}_{2} \mathrm{~S}_{2}
$$
236.16

55.95

55.68

5.12

5.12

2

$$
\begin{array}{ll}
-\mathrm{CH}_{2}-\mathrm{CH}=\mathrm{CH}_{2}-\mathrm{CH}_{3} & \mathrm{C}_{11} \mathrm{H}_{12} \mathrm{~N}_{2} \mathrm{~S}_{2} \\
236.16
\end{array}
$$

55.95

5.12

55.65

5.21

\subsection{6}

5.64

$\mathrm{C}_{12} \mathrm{H}_{14} \mathrm{~N}_{2} \mathrm{~S}_{2}$

57.89

5.68

$11.19 \quad 25.61$

11.2525 .26

$4-\mathrm{CH}_{2}-\mathrm{CH}=\mathrm{CH}-\mathrm{C}_{2} \mathrm{H}_{5}$

$\mathrm{C}_{12} \mathrm{H}_{14} \mathrm{~N}_{2} \mathrm{~S}_{2}$ 250.39

57.56

5.64

$\begin{array}{ll}11.19 & 25.61\end{array}$

$57.69 \quad 5.68$

$11.10 \quad 25.31$

5

$$
-\mathrm{CH}_{2}-\mathrm{CH}=\mathrm{C}\left(\mathrm{CH}_{3}\right)_{2}
$$

$\mathrm{C}_{12} \mathrm{H}_{14} \mathrm{~N}_{2} \mathrm{~S}_{2}$ 250.39

57.56

5.64

$11.19 \quad 25.61$

57.67

5.70

$11.03 \quad 25.55$

6

$-\left(\mathrm{CH}_{2}\right)_{4}-\mathrm{CH}=\mathrm{CH}_{2}$
94.8

70.8

61.2

29.0-32.0

87.5

$33.5-36.0$

72.7

42.0-44.0

85.8

39.0-40.5 substituent at position 3 only in the range of experimental exactness.

The synthesized compounds were tested for antimicrobial activity against: 2 strains of Candida albicans, Escherichia coli, Staphylococcus aureus and 1 strain of fungi Aspergillus niger and dermatophyte Trichophyton mentagrophytes var. interdigitale. The new compounds have manifested significant antimicrobial activity only against the $\mathrm{G}^{+}$bacteria Staphylococcus aureus (Table 2) and Candida albicans. For Candida albicans CCY 29-3-112 6-amino-2-n-pentylthiobenzothiazole (APB) [2], a good antimycotic agent [8], was used as standard. Two of the new compounds, 3 and $\mathbf{4}$, both with alkenyl substituents of right chain and $\mathrm{C}_{5}$ were better than APB (Table 3). The best antibacterial activity against Staphylococcus aureus, both against strain ATEC 25923 and a clinical isolate, was manifested by compund $\mathbf{6}$ with alkenyl substituent of right chain $\mathrm{C}_{6}$ (Table 2). The mechanism of candida inhibition by 2-alkenylthio-6aminobenzothiazoles $\mathbf{1}$ - $\mathbf{6}$ is probably the same as in the case of APB [11, 12]. For this compound the mechanism of inhibition has been studied for Saccharomyces cerevisiae as well. The mechanism of action in both cases is based on blocking the ergosterol biosynthesis pathway 
by demethylation of the intermediates. The differences between Candida albicans and Saccharomyces cerevisiae are caused by the different sensitivity of both microorganisms against APB.

6-Amino-2-n-pentylthiobenzothiazole inhibits ergosterol biosynthesis in Candida albicans and Saccharomyces cerevisiae at the level of sterol 4-demethylation. This effect leads to a decrease in ergosterol contents in treated cells, accompanied by an increase in the contents of aberrant 4-methylated sterols. Such a shift in sterol composition is known to impair cellular functions and may lower the viability of the fungal cells treated with the inhibitor.

Table 2. Antibacterial activity of 2-alkenylthio-6-aminobenzothiazoles.

$\mathrm{MIC} / \mu \mathrm{g} \mathrm{cm}^{-3}$

Bacteria

$\begin{array}{llllll}1 & 2 & 3 & 4 & 5 & 6\end{array}$

\begin{tabular}{|c|c|c|c|c|c|c|}
\hline $\begin{array}{l}\text { Staphylococcus aureus } \\
\text { ATEC } 25923\end{array}$ & 128 & 128 & 64 & 128 & 128 & 32 \\
\hline $\begin{array}{l}\text { Staphylococcus aureus } \\
\text { clinical isolate }\end{array}$ & 128 & 128 & 64 & 128 & 128 & 32 \\
\hline
\end{tabular}

MIC = the lowest of the concentrations used that fully inhibited the growth of Staphylococcus aureus.

Table 3. Anticandidous activity of 2-alkenylthio-6-aminobezothiazoles.

Candida albicans

strains

CCY 29-3-112

Clinical isolate

\begin{tabular}{lllllll}
\multicolumn{7}{c}{$\mathrm{MIC} / \mu \mathrm{g} \mathrm{cm}^{-3}$} \\
\hline $\mathbf{1}$ & $\mathbf{2}$ & $\mathbf{3}$ & $\mathbf{4}$ & $\mathbf{5}$ & $\mathbf{6}$ & $\mathbf{A P B}$ \\
62.5 & 31.25 & 15.6 & 15.6 & 62.5 & 31.25 & 31.25 \\
125 & 125 & 62.5 & 62.5 & 62.5 & 31.25 & -
\end{tabular}

MIC = the lowest of the concentrations used that fully inhibited the growth of Candida albicans.

APB = 6-amino-2-n-pentylthiobenzothiazole.

- $\quad=$ not tested.

The optimum structure of the synthesized compounds and 6-amino-2-n-pentylthiobenzothia-zole has been calcu- lated by quantum chemical AM1 method with standard parametrisation and full optimization [13]. Additive 
properties were taken into account for lipophilicity calculations [14]. On the basis of our study we could expect that for the best biological activity lipophilicity of the alkenyl group is in the range of $2.2-2.7$ and this substituent is approximately in the plane of the molecule.

Table 4. Rotation angles of the alkyl groups of 2-alkylthio-6-aminobenzothiazoles.

\begin{tabular}{|c|c|c|c|c|c|c|c|}
\hline \multirow[t]{2}{*}{ Compound } & \multirow[t]{2}{*}{$\mathrm{R}$} & \multicolumn{5}{|c|}{ Angles / degrees } & \multirow[b]{2}{*}{$C^{3} C^{4} C^{5} C^{6}$} \\
\hline & & $\mathrm{NCSC}^{1}$ & $\mathrm{CSC}^{1} \mathrm{C}^{2}$ & $\mathrm{SC}^{1} \mathrm{C}^{2} \mathrm{C}^{3}$ & $C^{1} C^{2} C^{3} C^{4}$ & $C^{2} C^{3} C^{4} C^{5}$ & \\
\hline 1 & $-C^{1}-C^{2}-C^{3}=C^{4}$ & 0 & -179 & 180 & 133 & - & - \\
\hline 2 & $-C^{1}-C^{2}=C^{3}-C^{4}$ & 1 & 175 & 113 & 179 & - & - \\
\hline 3 & $-C^{1}-C^{2}-C^{3}-C^{4}=C^{5}$ & 0 & 180 & 179 & 179 & 133 & - \\
\hline 4 & $-C^{1}-C^{2}=C^{3}-C^{4}-C^{5}$ & 0 & 176 & 112 & 179 & 1 & - \\
\hline 5 & $-C^{1}-C^{2}=C^{3}(C)_{2}{ }^{4,5}$ & -1 & -176 & -109 & 0 & $179^{a}$ & - \\
\hline 6 & $-C^{1}-C^{2}-C^{3}-C^{4}-C^{5}=C^{6}$ & 0 & 179 & 176 & 74 & 179 & -135 \\
\hline APB & $-C^{1}-C^{2}-C^{3}-C^{4}-C^{5}$ & 0 & 180 & 180 & 180 & 180 & - \\
\hline
\end{tabular}

a Angle $\mathrm{C}^{1} \mathrm{C}^{2} \mathrm{C}^{3} \mathrm{C}^{5}$

One of the most important conditions of efficiency of 2-alkylthio-6-aminobenzothiazoles is the area of lipophilicity spreading. The most effective derivatives have this area enlarged so that it covers the sulphur atom and a great part of the alkyl chain. It is evident from Figure 1 where the distribution on the Van der Waals surfaces of the molecules of compounds 1, 4 and APB are shown. White colour in the case of compounds $\mathbf{4}$ and APB indicates the maximum of lipophilicity. As we have expected, the alkenyl substituent has no effect on the electronic structure, but dihedral angles are in the range $47-74^{\circ}$ from the plane of the molecule. Rotation angles are in Table 4 and the structures of compounds 3, $\mathbf{4}$ and $\mathbf{6}$ are in Figure 2. The minimum dihedral angle has been calculated for the alkenyl substituent of compound $\mathbf{3}$ (one with the best anticandidous activity).

\section{Experimental}

General

The alkylating agents were purchased from the Aldrich Chemical Co. and used without further purification. 6Amino-2-benzothiazolinethione (6-amino-2-mercaptobenzothiazole) was prepared and purified according to [10]. Melting points were determined on a Kofler hotstage apparatus and are uncorrected. ${ }^{1} \mathrm{H}$ NMR spectra were obtained in $\mathrm{CDCl}_{3}$ solution on TESLA BS 587 spectrometer $(80 \mathrm{MHz})$. Tetramethylsilane (TMS) was used as internal standard.

Antimicrobial tests: Escherichia coli and Staphylococcus aureus were cultivated on Mueller-Hinton agar overnight $(18 \mathrm{~h})$ at $37^{\circ} \mathrm{C}$. Candida albicans was cultivated $24 \mathrm{~h}$ at $37^{\circ} \mathrm{C}$ in Sabouraud soil under shaking. 

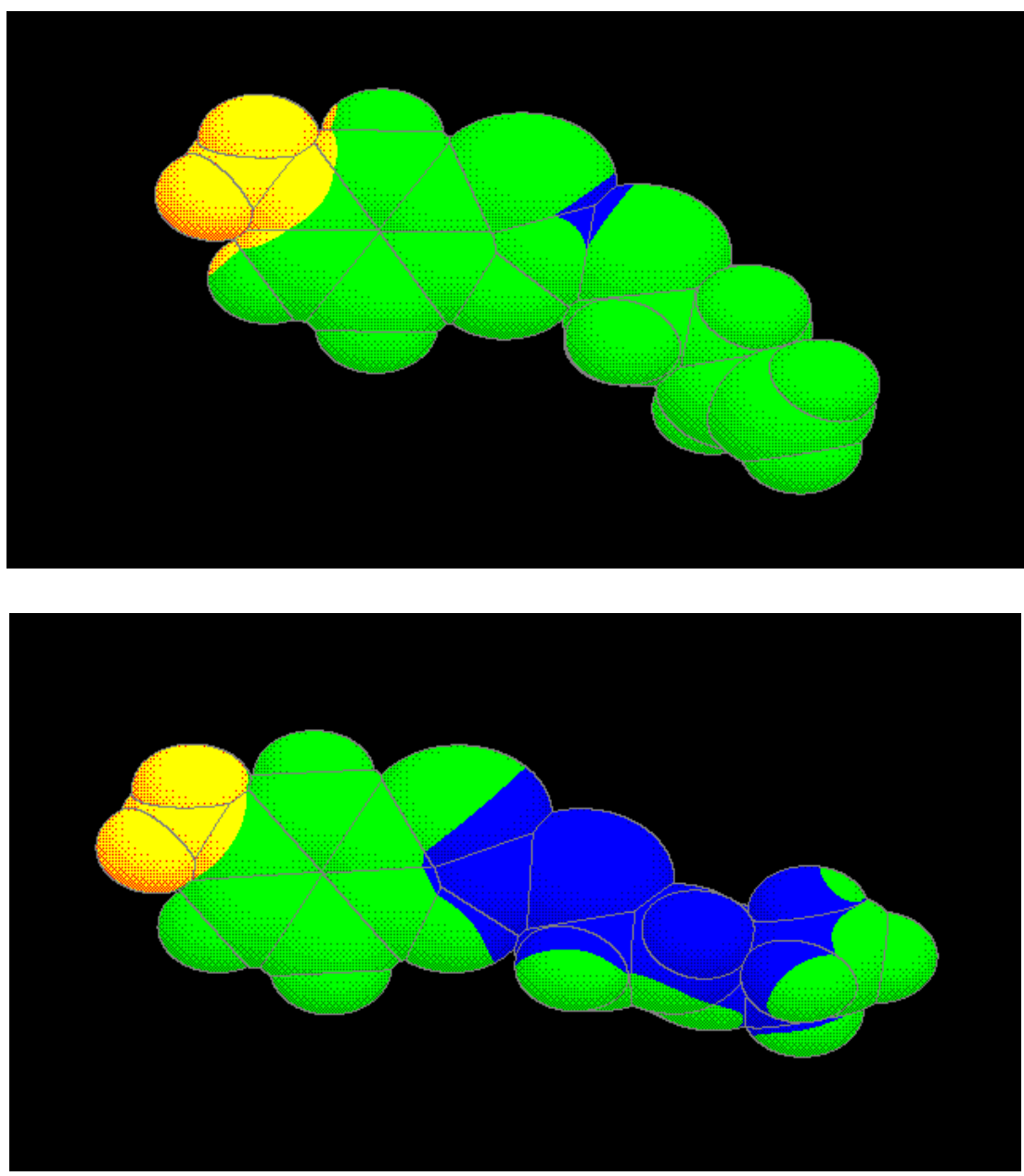

APB

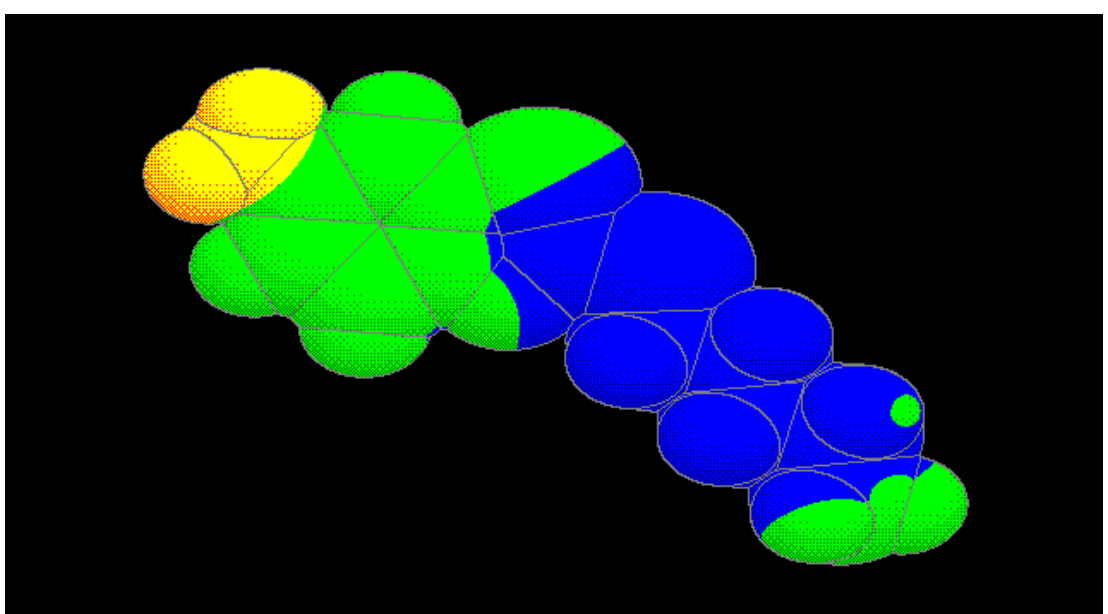

Figure 1. Distribution of lipophilicity on the Van der Waals surface (the highest value of the lipophilicity is in the blue color area) 

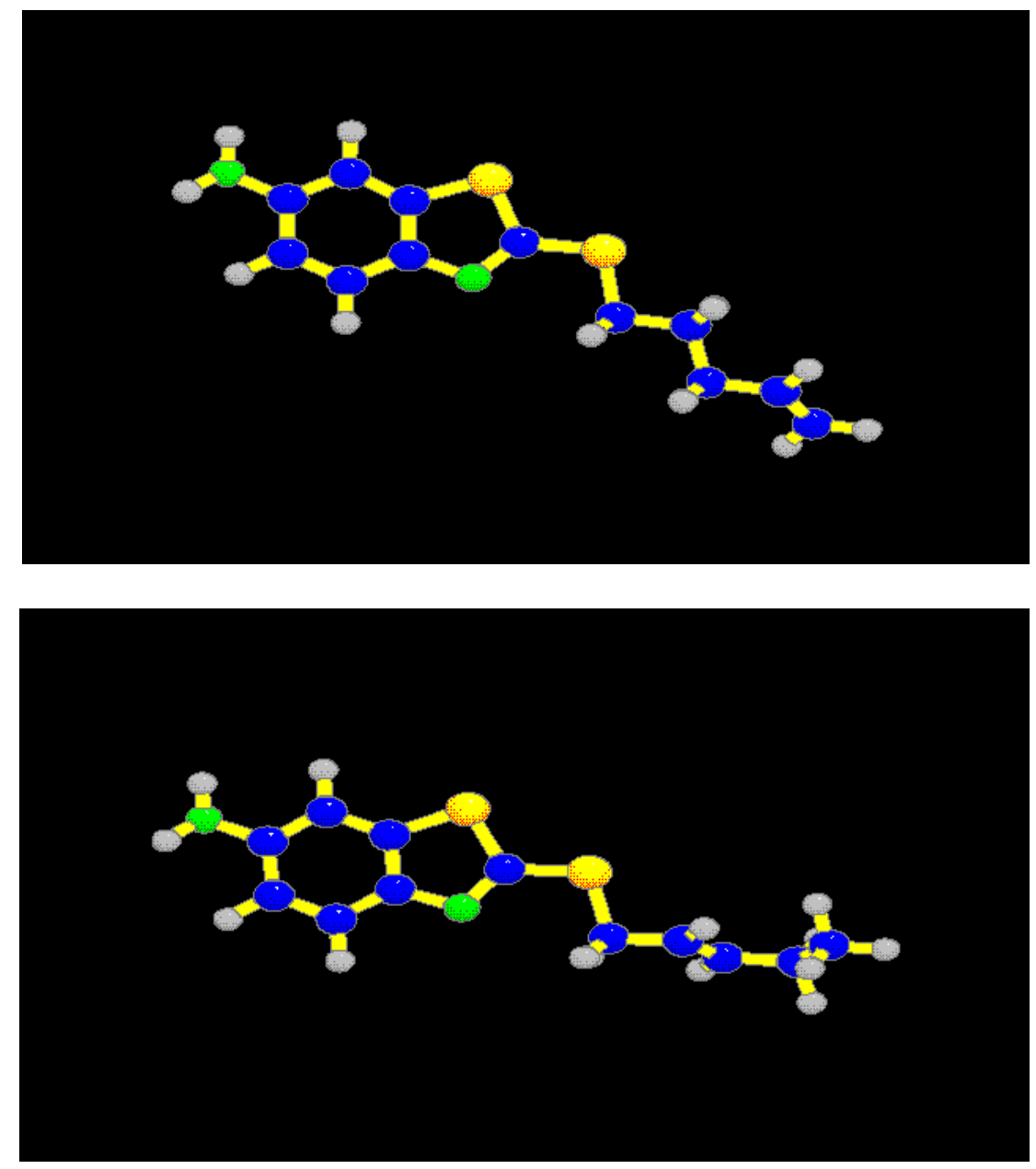

6

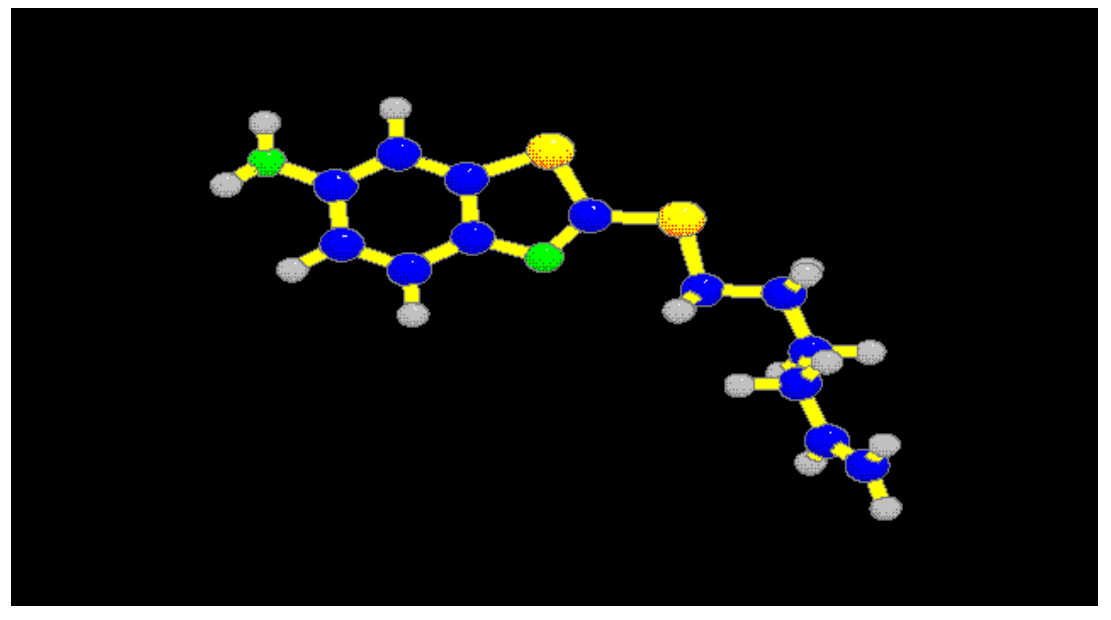

Figure 2. Structures of the compounds with the best antimicrobial activities.

(Sulfur atoms are yellow, nitrogen atoms are green). 
Results of ${ }^{1} \mathrm{H} \mathrm{NMR}$ analysis $\left(80 \mathrm{MHz} ; \mathrm{CDCl}_{3}\right)$

6-Aminobenzothiazole skeleton

$\delta 7.65(\mathrm{H}-4, \mathrm{~d}, J=8.6 \mathrm{~Hz}) ; 6.98(\mathrm{H}-7, \mathrm{~d}, J=2.2 \mathrm{~Hz})$; $6.75(\mathrm{H}-5, \mathrm{dd}, J=8.6,2.2 \mathrm{~Hz}) ; 3.7$ - $3.6\left(\mathrm{NH}_{2}, \mathrm{bs}\right)$.

-SR substituents

$1\left(\mathrm{R}=-\mathrm{CH}_{2} \mathrm{CH}_{2} \mathrm{CH}=\mathrm{CH}_{2}, \delta 5.88(=\mathrm{CH}, \mathrm{m}, J=17.1\right.$, $10.4,6.5 \mathrm{~Hz}) ; 5.10,5.08\left(=\mathrm{CH}_{2}, \mathrm{~m}, J=17.1,10.4,1.6\right.$ $\mathrm{Hz}) ; 3.34\left(\mathrm{SCH}_{2}, \mathrm{t}\right) ; 2.54\left(\mathrm{CH}_{2} \mathrm{C}=, \mathrm{q}\right)$.

$2\left(\mathrm{R}=-\mathrm{CH}_{2} \mathrm{CH}=\mathrm{CHCH}_{3}\right.$ (trans)): $\delta 5.71(=\mathrm{CH}, \mathrm{m}, J=$ $17.4 \mathrm{~Hz}, 2 \mathrm{H}) ; 3.86\left(\mathrm{SCH}_{2}, \mathrm{~d}\right) ; 1.68\left(\mathrm{CH}_{3}, \mathrm{~d}\right)$.

$3\left(\mathrm{R}=-\mathrm{CH}_{2} \mathrm{CH}_{2} \mathrm{CH}_{2} \mathrm{CH}=\mathrm{CH}_{2}\right): \delta 5.81(=\mathrm{CH}, \mathrm{m}, J=$ $17.2,9.9,6.3 \mathrm{~Hz}) ; 5.03,4.97\left(=\mathrm{CH}_{2}, \mathrm{~m}, J=17.2,9.9,0.8\right.$ $\mathrm{Hz}) ; 3.27\left(\mathrm{SCH}_{2}, \mathrm{t}\right) ; 2.18\left(\mathrm{CH}_{2} \mathrm{C}=, \mathrm{q}\right) ; 1.87,\left(\mathrm{CH}_{2}, \mathrm{qi}\right)$.

$4\left(\mathrm{R}=-\mathrm{CH}_{2} \mathrm{CH}=\mathrm{CHCH}_{2} \mathrm{CH}_{3}\right): \delta 5.59(\mathrm{CH}=\mathrm{CH}, \mathrm{t})$; $3.95\left(\mathrm{SCH}_{2}, \mathrm{~d}\right) ; 2.15\left(\mathrm{CH}_{2}, \mathrm{~m}\right) ; 0.97,\left(\mathrm{CH}_{3}, \mathrm{t}\right)$.

$5\left(\mathrm{R}=-\mathrm{CH}_{2} \mathrm{CH}=\mathrm{CH}\left(\mathrm{CH}_{3}\right)_{2}\right): \delta 5.40(=\mathrm{CH}, \mathrm{t}, J=7.8$ $\mathrm{Hz})$; $3.92\left(\mathrm{SCH}_{2}, \mathrm{~d}\right) ; 1.73,\left(\mathrm{CH}_{3}, \mathrm{~s}, 6 \mathrm{H}\right)$.

$6\left(\mathrm{R}=-\mathrm{CH}_{2} \mathrm{CH}_{2} \mathrm{CH}_{2} \mathrm{CH}_{2} \mathrm{CH}=\mathrm{CH}_{2}\right): \delta 5.81(=\mathrm{CH}, \mathrm{m}$, $J=16.7,9.9,6.7 \mathrm{~Hz}) ; 4.98,4.90\left(=\mathrm{CH}_{2}, \mathrm{~m}, J=16.7,9.9\right.$, $1.3 \mathrm{~Hz}) ; 3.27\left(\mathrm{SCH}_{2}, \mathrm{t}\right) ; 2.05\left(\mathrm{CH}_{2} \mathrm{C}=, \mathrm{q}\right) ; 1.7,\left(\mathrm{CH}_{2}-\mathrm{CH}_{2}\right.$, $\mathrm{m}, 4 \mathrm{H})$.

APB $\left(\mathrm{R}=-\mathrm{CH}_{2} \mathrm{CH}_{2} \mathrm{CH}_{2} \mathrm{CH}_{2} \mathrm{CH}_{2}\right): \delta 3.26\left(\mathrm{SCH}_{2}, \mathrm{t}\right)$; $1.74\left(\mathrm{CH}_{2}, \mathrm{qi}\right) ; 1.40\left(\mathrm{CH}_{2} \mathrm{CH}_{2}, \mathrm{~m}, 4 \mathrm{H}\right) ; 0.90,\left(\mathrm{CH}_{3}, \mathrm{t}\right)$.

\section{2-Alkenylthio-6-aminobenzothiazoles 1 - 4}

To a mixture of 6-amino-2-benzothiazolinethione (9.1 $\mathrm{g}, 0.05 \mathrm{~mol})$ and potassium hydroxide $(6.5 \mathrm{~g}, 0.1 \mathrm{~mol})$, dissolved in water $\left(10 \mathrm{~cm}^{3}\right)$, dimethylformamide $\left(25 \mathrm{~cm}^{3}\right)$ was added under mechanical stirring. Immediately afterwards alkenyl bromide $(0.05 \mathrm{~mol})$ was added in one portion. After 1 hour of stirring without heating the mixture was poured onto crushed ice $(600 \mathrm{~g})$ and after the first signs of solidifying an equal amount of water was added to the mixture.

Samples for analysis and antimicrobial testing were crystallized from diethyl ether - isohexane (1:1) using charcoal.
Acknowledegements: Our thanks are due to Dr. E. Solèániová for ${ }^{1} \mathrm{H}$ NMR spectra and to Ing. E. Greiplová for elemental analysis (Institute of Chemistry, Faculty of Natural Sciences, Comenius University, Bratislava).

\section{References}

1. Sidóová, E.; Odlerová, Z.; Volná, F.; Blöckinger, G. Chem. Zvesti 1979, 33, 830.

2. Sidóová, E.; Kuchta, T.; Zemanová, M. Straková, H.; CS Pat. 261699, 1988.

3. Kuchta, T.; Straková, H.; Sidóová, E. Cs. Farmacie 1989, 38, 139.

4. Bujdáková, H.; Kuchta, T.; Sidóová, E. Acta Fac. Rerum Natur. Univ. Comen. Microbiologia 1991, 19 $-20,37$.

5. Kuchta, T.; Bujdáková, H.; Sidóová, E. Folia Microbiologica 1989, 34, 504.

6. Kuchta, T.; Bujdáková, H.; Sidóová, E.; Neslusanová, E. Acta Fac. Rerum Natur. Univ. Comen., Microbiologia 1990, 17 - 18, 49.

7. Bujdáková, H.; Kuchta, T.; Sidóová, E.; Gvozdjaková, A. FEMS Microbiology Letters 1993, 112, 329.

8. Bujdáková, H.; Múcková, M.; Klobu_icky, M.; Sidóová, E. Mycopathologia 1995, 130, 141.

9. Kuchta, T.; Sidóová, E. Cs. Farmacie 1989, 38, 310.

10. Blöckinger, G.; Sutoris, V. CS Pat. 168746, 1975.

11. Kuchta, T.; Bartková, K.; Kubinec, R. Biochem. Biophys. Res. Commun. 1992, 189, 85.

12. Kuchta, T.; Léka, Cs.; Farka_, P.; Bujdáková, H.; Belajová, E.; Russell, N. J. Antimicrob. Agents. Chemother. 1995, 39, 1538 .

13. Dewar, M. J. S.; Zoebisch, E.; Healy, E.; Stewart, J. P. P. J. Am. Chem. Soc. 1985, 107, 3902.

14. Ertl, P. Chem. Listy 1992, 86, 465.

Sample Availability: Samples are available from the authors. 